\title{
Comments on Flores And Bazzalo (2004)
}

\author{
Leonardo L. Wedekin ${ }^{1, *}$, FÁbio G. Daura-Jorge ${ }^{1}$ and Paulo C. Simões-Lopes ${ }^{1}$
}

The article entitled "Home ranges and movement patterns of the marine tucuxi dolphin, Sotalia fluviatilis, in Baía Norte, southern Brazil" (Flores and Bazzalo, 2004)², published in LAJAM 3(1): 37-52, merits further comments as follows:

\section{Home range methods}

The concept and methods to estimate animals' home range have been used inadequately by researchers worldwide (Harris et al., 1990). It is not our intention to make a review about this subject here, especially because this was already done by other authors (see Harris et al., 1990; Powell, 2000; Jacob and Rudran, 2003). Nevertheless, we believe that some misuses of the home range methods and some methodological details omitted by Flores and Bazzalo (2004) deserve further attention.

The first point relates to the calculation of sufficient sample size. Stickel (1954) described a simple method to calculate sample sufficiency considering that the range of an individual tends to increase at successive sighting locations, rapidly at first and subsequently more slowly. Thus, when additional locations are added to the range estimation and the size of the range ceases to increase (or reaches an asymptote), it means that the sample size is sufficient for that individual and the home range estimation better reflects the true range. When the range size is plotted against the number of locations, a researcher may obtain an observation-area curve for each animal. Odum and Kuenzler (1955) then suggested the use of an optional and arbitrary 'one-percent level', which means that the researcher may reach the sample sufficiency when each additional observation of an animal will produce less than a one-percent increase in the area of the home range estimate. It is important to collect a large number of fixes from several individuals of different ages and sexes to determine approximately at which point home range size reaches an asymptote (Harris et al., 1990). The extrapolation of sample size sufficiency from other studies or generalizations may be ineffective because the relationship between sample size and home range estimate can vary among species (Cameron and Spencer, 1985). Moreover, the ideal procedure is to plot the observation-area curve for each individual being analyzed and consider in the analysis only those animals in which the curve reached an asymptote, discarding the estimates otherwise.

It is not clear whether Flores and Bazzalo plotted observation-area curves for each individually identified dolphin prior to pooling the data as shown in Figure 2 (page 40; Flores and Bazzalo, 2004). If not, such graphs should be presented and discussed, so as to help justify the authors' argument that the observation-area curve reached an asymptote after 30 locations, since the observation-area curve in Figure 2 does not appear to stabilize until 45 locations.

The kernel observation-area curve did not clearly stabilize (Figure 2; Flores and Bazzalo, 2004) because this home range method is not appropriate for the verification of sample size sufficiency through the observation-area curve procedure. One reason why a kernel home range estimate is not a suitable method for estimating sample size sufficiency is because the kernel density is affected by sample size, type of kernel, point concentration and distribution. Each data set may produce a different estimation, and the observation area curve may behave in an unpredictable fashion as shown in Figure 2 of the Flores and Bazzalo (2004) article.

The kernel estimator produces a distribution of an animal's position in the plane (or utility distribution) based on a probability density function from a random sample of locational observations (Worton, 1989), and it is considered the best home range estimator available (Powell, 2000). There are two different approaches for data analysis using the kernel method, the fixed and the adaptive kernel (for details see Worton, 1989). We only know which kernel was used in the work by Flores and Bazzalo (2004) because the "Animal Movement Analyst Extension" of the Arcview software (Hooge and Eichenlaub, 1997), used by the authors, only performs the fixed kernel procedure.

The kernel method has an important component called $h$ or smoothing parameter, and choosing its value (or the band width) is one of the most important and, at the same time, difficult step while using a kernel estimator (Powell, 2000). For a given kernel and sample size we need to find the "best" value of $h$, and there are many procedures available to calculate it (Worton, 1989). The "Animal Movement Analyst Extension" (Hooge and Eichenlaub, 1997) has at least three possible options from which to choose the smoothing parameter. Flores and Bazzalo (2004) did not state what procedure was used for the choice of the smoothing parameter in the home range estimates of their work.

\footnotetext{
${ }^{1}$ Laboratório de Mamíferos Aquáticos (LAMAQ), Departamento de Ecologia e Zoologia, Universidade Federal de Santa Catarina, Florianópolis, SC, 88040-970, Brazil.

* Corresponding author: lwedekin@hotmail.com.

${ }^{2}$ We agree with Monteiro Filho et al. (2002) and consider the marine form of the genus Sotalia a distinct species from the riverine form. We will use in our article the name Sotalia guianensis, in contrast with the view by Flores and Bazzalo (2004) who considered both forms of the genus Sotalia one single species - Sotalia fluviatilis.
} 
Finally, the kernel method assumes independence between successive observations (or absence of spatial autocorrelation) (Worton, 1989), and reference to the level of autocorrelation of data should be included in home range studies (Harris et al., 1990). Although there are studies discussing the potential deleterious effect of destructive subsampling or restrictive sampling to achieve independence (e.g. Reynolds and Laundre, 1990; Rooney et al., 1998; Solla et al., 1999), this assumption should be considered when using kernel methods and was not addressed by Flores and Bazzalo (2004).

The parameters associated with each home range analysis, many of them stated above, are important and should be included when home range sizes and shapes are quoted. Otherwise there is a risk that the results presented are meaningless to anyone other than the author of the study (Harris et al., 1990), which makes it more difficult to assess the suitability of the method under different circumstances.

\section{Marine protected area design}

Flores and Bazzalo (2004) found that the percentage of marine tucuxi's overall home range within the EPA of Anhatomirim could be considered moderate to high depending on the estimator, and thus concluded that the EPA is instrumental in protecting the southernmost population of the species.

Other previous works suggested that the design of the EPA of Anhatomirim is not effective in accomplishing its objective because it does not embrace all the crude distribution of the southernmost population of this species (Wedekin et al., 2002; Wedekin et al., in press). Further studies have focused on the distribution of the environmental impacts that pose a threat to marine tucuxi conservation, and it was found that the origin of these impacts extrapolate not only the distribution of the dolphins, but also the marine habitats of Norte Bay (Wedekin and DauraJorge, 2003). An effective design of the EPA of Anhatomirim, considering its goal, should cover the distribution of the dolphins and the distribution of the human activities that originate these impacts (Wedekin and Daura-Jorge, 2003).

The marine tucuxi population may spend a great amount of time within the limits of the EPA of Anhatomirim (Flores, 1999), but our knowledge is still limited to assume that the EPA is effective. For example, we do not know where animals are affected by accidental entanglement in fishing gear, and we do not know whether time spent in certain habitats coincides with the importance of that habitat, indeed a potential caveat of most home range estimators (Powell, 2000).

It is also important to remember that the management category of this marine protected area, according to the Brazilian legislation, is not subject to the proposition of buffer zones, as proposed in previous studies (Wedekin and Daura-Jorge, 2003; Flores and Bazzalo, 2004). Possible alternatives would be to redesign the EPA, create new conservation mechanisms and/or legislation, or to focus on the management actions both inside and outside of the marine protected area.

But it is important to reinforce the conclusion that the design of the EPA of Anhatomirim has many frailties: (1) discrepancy between the administrative limits and the distribution of the dolphins (Wedekin et al., 2002; Wedekin and Daura-Jorge, 2003), including individual home ranges (see Flores and Bazzalo, 2004); (2) discrepancy between the administrative limits and sources of potential impacts posing threats to dolphin conservation (Wedekin and Daura-Jorge, 2002); and (3) aquatic boundaries difficult to detect visually. The latter problem may be important because most of the artisanal fishermen of Norte Bay do not possess Global Positioning System (GPS) equipments and are not able to know when they are inside this marine protected area (LW, pers. obs.). The EPA could be designed entirely based on natural visual marks, a 'privilege' that cannot be found in most marine protected areas.

It is important to state that the conclusions presented here agree that the EPA of Anhatomirim is of great importance in the protection of the resident population of marine tucuxi of Norte Bay, especially from the impacts originating from the intense boat traffic. However, frequently there are many negative forces or vectors in a conservation scenario as is the case with marine tucuxi at the Norte Bay (Wedekin et al., 2005). Accordingly, a conservation mechanism such as the EPA of Anhatomirim should address this complex scenario, which includes several impacts and their respective human actions that originate them.

Based on what we have argued and following the precautionary approach which must be followed in conservation biology decision-making, we think it is premature to state that the EPA of Anhatomirim fulfills its main objectives, as its effectiveness, among other things, depends on an adequate design.

\section{Parametric after nonparametric statistics}

Flores and Bazzalo (2004) used nonparametric approaches, such as the Mann-Whitney $U$ and the Kruskal-Wallis tests, to compare movements of the marine tucuxi between years and among seasons, respectively. However, the authors used a parametric Tukey test to show the sources of variation in the seasonal comparison in the movement pattern results, Multiple comparison tests such as the Tukey test, in general, have the same underlying assumptions as does the analysis of variance (ANOVA) (i.e. normality and homogeneity of variance) and are usually 
performed after the rejection of the null hypothesis of an ANOVA, with the exception of atypical situations (Zar, 1999). A few questions emerged related to the data analysis procedure in the work by Flores and Bazzalo (2004): (a) Did the data meet the assumptions of the ANOVA and Tukey test (i.e. normality and homogeneity of variance)? (b) If so, why were non-parametric tests preferred, instead of more powerful alternatives such as the ANOVA? (c) Why were non-parametric and parametric procedures used together to test the same or related hypothesis from the same data set?

The latter question, which is the central point of this critique, reflects a common mistake usually found in scientific articles. Although changing the procedure to a more statistically sound analysis may not produce differences in their results, we consider it a frivolous procedure that should not be replicated. The use of a multiple comparison, a posteriori, parametric test should not be used after the rejection of the null hypothesis tested by a non-parametric test. One feasible alternative to show the sources of variation after the rejection of the null hypothesis by the nonparametric Kruskal-Wallis test would be to simply present graphically the results obtained (e.g. through box-plots).

\section{Acknowledgements}

We wish to thank Maurício Graipel, Vitor Q. Piacentini and two anonymous referees who kindly read and made comments which greatly improved the manuscript, and Ginny Klie for an English review and suggestions.

\section{References}

CAmeron, G.N. And SPEncer, S.R. (1985) Assessment of spaceuse patterns in the hispid cotton rat (Sigmodon hispidus). Oecologia 68: 133-139.

FLORES, P.A.C. (1999) Preliminary results of a photoidentification study of the marine tucuxi, Sotalia fluviatilis, in Southern Brazil. Marine Mammal Science 15: 840-847.

Flores, P.A.C. AND BAzZAlo, M. (2004) Home ranges and movement patterns of the marine tucuxi dolphin, Sotalia fluviatilis, in Baía Norte, southern Brazil. The Latin American Journal of Aquatic Mammals 3: 37-52.

Harris S., Cresswell, W.J., Forde, P.G., Trewhella, W.J., WoOllard, T. AND Wray, S. (1990) Home-range analysis using radio-tracking data - a review of problems and tecniches particularly as applied to the study of mammals. Mammal Review 20: 97-123.

Hooge, P.N. and Eichenlaub, B. (1997) Animal Movement Extension to ArcView (version 1.1). Alaska Biological Science Centre, United States Geological Survey, Anchorage, AK, USA.

JACOB, A.A. AND RUDRAN, R. (2003) Radiotelemetria em estudos populacionais. Pages 285-342 in Cullen JR., L., RUdRAN, R. AND Valladares-Padua, C. (Eds) Métodos de estudos em biologia da conservação \& Manejo da vida silvestre. Editora da UFPR, Curitiba, PR, Brazil.

Monteiro Filho, E.L.A., Monteiro, L.R. And Reis, S.F. (2002) Skull shape and size divergence in dolphins of the genus Sotalia: a tridimensional morphometric analysis. Journal of Mammalogy 83: 125-134.

Odum, E.P. AND KUENZLER, E.J. (1955) Measurement of territory and home range size in birds. The Auk 72: 128-137.

Powell, R.A. (2000) Animal Home Ranges and Territories and Home Range Estimators. Pages 65-110 in Boitani, L. AND Fuller, T.K. (Eds) Research Techniques in Animal Ecology: Controversies and Consequences. Columbia University Press, New York, NY, USA.

ReYnolds, T.D. AND LaundRE, J.W. (1990) Time intervals for estimating pronghorn and coyote home ranges and daily movements. Journal of Wildlife Management 54: 316-322.

Rooney, S.M., Wolfe, A. And Hayden, T.J. (1998) Autocorrelated data in telemetry studies: time to independence and the problem of behavioural effects. Mammal Review 28: 89-98.

SOLLA, S.R., BONDURIANSKY, R. AND BROOKS, R. (1999) Eliminating autocorrelation reduces biological relevance of home range estimates. Journal of Animal Ecology 68: 221-234.

Stickel, L.F. (1954) A comparison of certain methods of measuring ranges of small mammals. Journal of Mammalogy 35: 1-15.

Wedekin, L.L. and Daura-Jorge, F.G. (2003) A efetividade da APA de Anhatomirim na conservação do boto-cinza, Sotalia guianensis, na Baía Norte, sul do Brasil. Pages 221 227 in Anais do II Simpósio de áreas Protegidas, Pelotas, RS, Brazil.

Wedekin, L.L., Daura-Jorge, F.G. AND Simões-Lopes, P.C. (2002) Desenho de unidades de conservação marinhas com cetáceos: estudo do caso do boto-cinza, Sotalia guianensis, na Baía Norte de Santa Catarina, Sul do Brasil. Pages 56-62 in Anais do III Congresso Brasileiro de Unidades de Conservação, 22-26 November, Fortaleza, CE, Brazil.

Wedekin, L.L., DA-Ré, M.A., Daura-Jorge, F.G. and SimõesLOPES, P.C. (2005) The use of a conceptual model to describe the conservation scenario of the estuarine dolphin within the Baía Norte (North Bay), southern Brazil. Natureza \& Conservação 3(1): 162-170.

Wedekin, L.L., Daura-Jorge, F.G., Piacentini, V.Q. And SimõesLOPES, P.C. (in press) Seasonal variations in spatial usage by the estuarine dolphin, Sotalia guianensis (Cetacea, Delphinidae) at its southern limit of distribution. Brazilian Journal of Biology.

WORTON, B.J. (1989) Kernel methods for estimating the utilization distribution in home-range studies. Ecology 70: 164-168.

ZAR, J.H. (1999) Biostatistical analysis. $4^{\text {th }}$ edition. Prentice Hall, Upper Saddle River.

Received 4 November 2004. Accepted 10 February 2006. 